\title{
Framework for Electromobility in the Slovak Republic and Its Application at the Local Level
}

\author{
Karol Hrudkay ${ }^{1}$, Jaroslav Jaroš ${ }^{2}$ \\ ${ }^{1}$ University of Žilina, University Science Park, Univerzitná 8215/1, 01026 Žilina, Slovak Republic \\ ${ }^{2}$ University of Žilina, University Science Park, Univerzitná 8215/1, 01026 Žilina, Slovak Republic
}

\begin{abstract}
The article deals with conditions for the development of electromobility in the Slovak Republic at the national level and at the level of municipalities. The framework at the national level is analysed, consisting of a set of strategic documents adopted at the level of government resolutions, some of which are devoted more generally to alternative fuels. The strength of the documents varies, from the material referred as a recommended one, through the material required by the European Commission to an action plan with defined measures. The second part outlines a possible approach of a municipality to a changing framework at the national level. Experiences are presented as municipalities have grasped the issue of electromobility in their documents and an example of good practice where the whole national framework was taken into account comprehensively. Possibilities to improve the readiness of municipalities for challenges related to the conceptual solution of electromobility at the level of municipalities were identified.
\end{abstract}

Keywords Electric vehicles, Charging infrastructure, National framework, Incentives, Municipalities

JEL H23, L98, H54, R58, O18

\section{Introduction}

In compliance with sustainable transport trends, alternative fuels have been increasingly preferred, with electricity probably playing a major role in the future. In the case of the deployment of battery electric vehicles (BEVs), a significant reduction in local emissions is achieved, which is very important in the case of settlements or agglomerations that are found in poorly ventilated basins and valleys.

In the previous period, the issue of starting a more massive extension of electromobility has been discussed in the professional circles, especially the relationship between insufficient charging infrastructure and a commercially insignificant number of electric vehicles (EVs). However, there are more obstacles to the user, the principal barriers being: cost of purchasing an electric vehicle, insufficient charging infrastructure, the lifetime of the electric energy storage device, range of an EV per single charge and charging time, unresolved interoperability, and safety of energy storage [11]. A significant shift has been recorded in all these aspects, but some of them can also be affected by policy at the national level.

\section{International context}

\subsection{Framework of European legislation}

Based on an analysis of European legislation on electromobility and related aspects, the following legislative framework has been identified:

- Directive 2014/94/EU of the European Parliament and of the Council on the deployment of alternative fuels infrastructure

- Directive 2009/28/EC of the European Parliament and of the Council on the promotion of the use of energy from renewable sources

- Directive 2009/29/EC of the European Parliament and of the Council amending Directive 2003/87/EC so as to improve and extend the greenhouse gas emission allowance trading scheme of the Community,

- Directive 2009/30/EC of the European Parliament and of the Council amending Directive 98/70/EC as regards the specification of petrol, diesel and gas-oil and introducing a mechanism to monitor and reduce greenhouse gas emissions,

- Directive 2009/31/EC of the European Parliament and of the Council on the geological storage of carbon dioxide,

- Decision No 406/2009/EC of the European Parliament and of the Council on the effort of Member States to 
reduce their greenhouse gas emissions to meet the Community's greenhouse gas emission reduction commitments up to 2020 ,

- Directive (EU) 2018/844 of the European Parliament and of the Council amending Directive 2010/31/EU on the energy performance of buildings and Directive 2012/27/EU on energy efficiency.

\subsection{International technical standards}

Progress in the area of international standardisation in terms of increasing the interoperability of individual components of the charging infrastructure and its security significantly affects the perceived level of attractiveness of electromobility from a user's perspective.

In this context, IEC 62196 (defines connector types) and IEC 61851 (defines charging modes) are considered to be the basic international standards, while the basic standard to ensure consistent communication between the charging infrastructure and the vehicle is ISO 15118 (defines communication interface between vehicle and grid).

All standards for electromobility constitute a very large set (its analysis is not the aim of this text). It is also important that at EU level the CEN, CENELEC and ETSI standardization authorities have been authorized since 2010 under mandate $\mathrm{M} / 468$ [3] to converge standards for charging electric vehicles. Furthermore, the issue of interoperability of collaborating systems in intelligent transport systems (M/453) [4] and the development of smart grid (M/490) [5] are subject to harmonisation efforts at a given level.

\section{Political framework and strategic documents of the Slovak Republic for electromobility}

\subsection{Legislative framework}

Considering the broad scope and interdisciplinarity of electromobility, the corresponding extent of related legislation is also extensive $[9,17,24]$, inter alia it includes these laws and regulations (as amended):

- Act No. 71/2013 Coll. on the provision of subsidies within the competence of the Ministry of Economy of the Slovak Republic,

- Regulation No. 358/2013 Coll. laying down the procedure and conditions for the implementation and operation of intelligent metering systems in the electro energy sector

- Act No. 135/1961 Coll. on land communications (Road Act),

- Act No. 8/2009 Coll. on road traffic,

- Act No. 582/2004 Coll. on local taxes and fees for municipal waste and minor construction waste,

- Act No. 563/2009 Coll. on tax administration (tax code),

- Act No. 137/2010 Coll. on air,

- Act No. 372/1990 Coll. on offences,

- Act No. 106/2018 Coll. on the operation of vehicles in road traffic,

- $\quad$ Act No. 251/2012 Coll. on energy,
- Act No. 555/2005 Coll. on energy efficiency of the buildings,

- Act No. 595/2003 Coll. on income tax,

- Act No. 158/2011 Coll. on the promotion of energy-saving and environmentally-friendly motor vehicles

- Regulation No. 9/2009 Coll. on implementing of the Act on road traffic,

- Act No. 50/1976 Coll. on the spatial plan and building code (building act).

It should be also noted that this framework is subject to frequent changes, which also result from the implementation of the following strategic documents into practice.

\subsection{Strategic documents}

Even under the influence of external influences (the need for cross-border cooperation) and EU influence (transposition of the Directive [1]), since 2012 a set of conceptual and strategic materials for electromobility has been elaborated in the SR in charge of the Ministry of Economy. The process was long and complicated, but particular steps are now being taken to promote electromobility at the national level.

Below a brief analysis of these documents is mentioned with an emphasis on the electromobility measures stated.

3.2.1. Strategy of electromobility development and its effect on Slovak economy [6]

The strategy aims to exploit the potential of electromobility. This is conditioned by defining the preconditions for its development in order to initiate the systematic support and development of electromobility as a promising automotive industry. It formulates several possible objectives for the development of electromobility in the areas of economy, ecology and science and research. It proposes 16 system measures to support the development of electromobility, namely:

- including the electromobility issues in all relevant state strategies and policies,

- stimulation of growth of sales of electric vehicles and plug-in hybrids (PHEV) in Slovakia,

- $\quad$ support of science, research, development and innovation,

- information campaign,

- education in schools; teaching of new skills and knowledge in the education system,

- low-emission urban zones,

- consistent application of the principles of green public procurement when purchasing motor vehicles,

- simplifying of the administrative process for the construction of charging infrastructure,

- reservation of a public parking place for the owner of the charging infrastructure in the place of residence,

- reservation of public parking space for the owner of a publicly available charging station,

- introduction of legislative conditions for the mandatory deployment of charging infrastructures during the construction of parking spaces,

- deployment of a national network of charging centres, 
- reservation of a parking place in the government's car parks and subsequently build public charging infrastructure,

- provision of a contribution to the municipality for the construction of publicly available charging infrastructure,

- favouring of parking and entrance to urban centres and pedestrian zones for electric vehicles,

- conversion of conventional vehicles to electric vehicles.

The partial objectives of the strategy, as well as the set of system tools for the promotion and development of electromobility, are only recommendations.

3.2.2 National political framework for the development of alternative fuels market [7]

From the point of view of electromobility (the fuel is electricity), the document aims to support the development of the alternative fuels market in the transport sector and the development of the relevant infrastructure through the measures set out, focusing on:

- an assessment of the current state and future development of the market for alternative fuels in the transport sector,

- national targets and targets for biofuels, electricity supply for transport, natural gas supply for transport and, where appropriate, hydrogen supply for road transport, including the deployment of alternative fuel infrastructure,

- measures needed to ensure that national targets and objectives are met and measures that may support the deployment of alternative fuels infrastructure in public transport services,

- identification of urban/suburban agglomerations, other densely populated areas and networks, where, depending on market needs, publicly accessible charging stations shall be installed in accordance with the electricity supply requirements for transport.

The document also defines a set of measures that are relevant for electromobility:

- $\quad$ stimulating the promotion of low-emission vehicles for all types of use (private sector, municipal fleets operating municipal waste distribution vehicles, postal operators and fleets of urban public transport and public passenger transport services),

- support of alternative fuel infrastructure,

- a $50 \%$ reduction of the registration fee for motor vehicles using alternative fuels,

- introduction of low-emission zones,

- ensuring that road users are informed about the location, type and facilities of charging and filling stations through intelligent transport systems,

- education in schools; awareness of new skills and knowledge in the education system.

3.2.3 National policy of deployment of infrastructure for alternative fuels in conditions of the Slovak Republic [8]

As the main alternative fuels with long-term oil substitute potential are defined: electricity, hydrogen, biofuels, syn- thetic and paraffin fuels, natural gas and liquefied petroleum gas (LPG) namely because of their possible concurrent and combined use by e.g. systems of dual-fuel technologies.

In terms of electromobility, it determines the technical specifications for charging stations as follows.

Charging stations for conventional alternating current (AC) charging for electric vehicles shall, for interoperability purposes, be equipped with at least socket-outlets or vehicles connectors of type 2 according to EN 62196-2. Charging stations for high-power AC charging for electric vehicles shall be equipped with at least type 2 connectors according to EN 62196-2 for interoperability purposes. High-voltage direct current (DC) charging stations for electric vehicles shall, for interoperability purposes, be equipped with at least the 'Combo 2' charging system connectors according to EN 62196-3.

3.2.4 Action plan of electromobility development in the Slovak Republic [9]

The Action plan of electromobility development in the Slovak republic is linked to the abovementioned strategies and transposition documents approved by the Government.

The Action plan is a follow-up to the 3 adopted clean mobility packages. The Action plan proposes measures to ensure that users will perceive low-emission mobility as a problem-free, even with the aspect of speeding up the roll-out of the infrastructure. The measures reflect the objectives following from the aforementioned strategic documents, which are commitments of the Slovak Republic $[1,2]$.

The development to date has significantly influenced the first project of direct support for the purchase of vehicles with alternative drive. There was a positive impact on the growth of sales of electric vehicles and support was used by 831 applicants, the number of registered electric vehicles in 2017 increased year-on-year by $350 \%$.

The measures of the Action plan are as follows:

- including the electromobility issues in all relevant national strategies and policies,

- continuity of direct support for the use of low-emission vehicles,

- long-term financial mechanism to support the development of charging infrastructure,

- support of research, development and production of batteries,

- information campaign,

- implementation of legal, technical and business environment for electromobility in Slovakia,

- accelerated depreciation of electric vehicles and charging stations for electric vehicles,

- $\quad$ applying the principles of green public procurement to the purchase of motor vehicles,

- differentiable marking of electric vehicles,

- use of dedicated lanes by electric vehicles,

- low emission zones,

- simplification of the administrative process for the construction of charging infrastructure, 
- legislative introduction of the obligation to build charging infrastructure during the construction of new parking places,

- installation of charging station at the parking places of state institutions,

- adaptation of the qualification in the area of electrical engineering for the production and servicing of electric vehicles.

3.2.5 of Revision and actualisation of National political framework for the development of alternative fuels market [10]

The document presents the state of implementation of the measures of the National political framework [7]. In terms of electromobility, the measures are largely fulfilled. One measure (ensuring information ...) is fulfilled or fulfilment lasts respectively and fulfilment of one measure is still ongoing (education at schools ...). The document also defines new measures for the National policy framework, but in the field of electromobility, in regard to the adopted Action plan, does not propose further concrete measures.

\section{Attitude of municipalities to the sys- temic dealing with electromobility}

\subsection{Electromobility in cities}

Big analyses from charging stations point to clear segmentation of users. In principle, it is possible to identify groups of users who charge BEV or PHEV at home, at work, charging specifically associate with other activities (shopping, culture, sport, ...) or while travelling (i.e., for distances longer than the electric range what typically concerns interurban journeys) [11].

Therefore it is evident that a significant proportion of BEV and PHEV users utilise the infrastructure at the place of residence, work or civic amenities. Furthermore, taking into account that already available electric vehicles are suitable for urban or regional transport, either for individual car transport or urban public transport (e-bus), service systems, etc., it is clear that electromobility in urban conditions is legitimate. The municipalities should, therefore, respond to this trend and deal within its competences conceptually, but taking into account local specificities.

\subsection{Attitude of municipalities}

In terms of solving of transport and mobility issues, smaller municipalities in the Slovak Republic are undersized in terms of personnel and in many cases do not have professionally competent capacities. Therefore it is in the interest of the municipality to address such a professional issue as conceptual design of electromobility in cooperation with external capacities that will bring a different perspective on the state, problems and processes in the municipality.

Local authorities' attitude to systemic and conceptual solutions of the electromobility issues varies considerably. In many cases, municipalities have not yet tackled this problem conceptually, but principally, larger municipalities are more concerned with electromobility.

Tab. 1 provides an overview of examples of how selected municipalities have dealt with the issue of electromobility.

The most successful municipalities in the conceptual approach of electromobility were the municipalities involved in the solution of projects in the framework of international projects or interest associations (e.g. clusters). There is the added value of sharing knowledge and experience on a larger scale.

It is also evident that the attitude of cities has changed over time (see the example of Bratislava), similarly as the attitude of the government has been changing.

Generally, it can also be seen that the municipalities did not take into account the effective national framework for electromobility analysed above.

The quality of output - conceptual or strategic document depends not only on the expertness of the stakeholders or subjects but also the available databases. The availability of data for its elaboration is usually closely related to the availability of other fine and relevant documents of the city and region, covering mainly the area of transport and economic and social aspects (Plan of economic and social development, Transport masterplan, Zoning plan, Sustainable urban mobility plan, Sustainable energy action plan, Cycling strategy, ...).

\subsection{A good practice example}

A good example of attitude to electromobility at the level of self-government is the Municipality of Senec. Municipality of Senec actively joined in the Interreg Danube Transnational Program by the Electric, Electronic and Green Urban Transport Systems (eGUTS) project [29], which aimed to develop a Local Action Plan (LAP) for the Municipality of Senec.

The process of LAP development consisted of several areas [25]:

- analysis of relevant documents at the national, regional and local levels,

- analysis of the current situation in the area of (e-)mobility, transport infrastructure and related areas,

- meetings, training, brainstorming,

- communication (phone calls, e-mail, teleconference, shared storage).

It should be noted that during the preparation of LAP only Plan of economic and social development and partially Zoning plan (in the process of changes) were available from the site of Municipality of Senec. The development of the Transport masterplan was interrupted at that time due to major changes in the infrastructure in the neighbourhood of the city. For this reason, face-to-face meetings with the responsible staff of the Municipal office were important, and they provided information to the authors of LAP that were not captured by any documents and materials. The LAP was prepared for the Municipality of Senec as a document with two parts - analytical and proposal ones - and annexes. 
Table 1. Strategic and conceptual documents dealing with the electromobility of Slovak municipalities

\begin{tabular}{|c|c|c|c|c|}
\hline Municipality & Document [Year of adoption] & Measure/activity/tool/project intention/target related to electromobility & $\begin{array}{c}\text { Framework } \\
\text { linkage }\end{array}$ & Ref. \\
\hline Košice & $\begin{array}{l}\text { Košice development program for } \\
\text { 2015-2020 (2025) [2015] }\end{array}$ & $\begin{array}{l}\text { - Increasing the capacity of parking places and its regulating in the central urban } \\
\text { zone and housing estates - favouring of low-emission vehicles (BEV, PHEV) in } \\
\text { the static traffic management system, } \bullet \text { Reducing of particulate matter in the city } \\
\text { - promoting alternative mobility, including electromobility in the city }\end{array}$ & No linkage & [12] \\
\hline Bratislava & $\begin{array}{l}\text { Development of electromobility in } \\
\text { the environment of the Slovak } \\
\text { capital Bratislava [2013] }\end{array}$ & $\begin{array}{c}\bullet \text { Gain sufficient experience from electric vehicle fleet operation } \bullet \text { Modify } \\
\text { pedestrian precinct access policy for traffic supply } \bullet \text { Active attitude to legislative } \\
\text { changes } \bullet \text { Create } 30 \text { additional free parking spaces reserved only for EV in city } \\
\text { centre } \bullet \text { Modify capacity assessment methodology for new investment con- } \\
\text { struction Note: the document assumes the adoption of the Municipality's strategy } \\
\text { to promote electromobility }\end{array}$ & $\begin{array}{l}\text { No linkage } \\
\text { - adopted } \\
\text { before } \\
\text { Framewok }\end{array}$ & [13] \\
\hline Bratislava & $\begin{array}{c}\text { Action plan on adaptation to the } \\
\text { adverse consequences of climate } \\
\text { change in the capital of the Slovak } \\
\text { Republic Bratislava for } 2017-2020 \\
\text { [2017] }\end{array}$ & $\bullet$ Support of electromobility in the city & No linkage & [14] \\
\hline Michalovce & $\begin{array}{l}\text { Economic and social development } \\
\text { program of the Municipality } \\
\text { Michalovce for 2016-2025 [2016] }\end{array}$ & - Electromobility of municipal police officers & No linkage & [15] \\
\hline Žilina & $\begin{array}{l}\text { Low carbon mobility action plan in } \\
\text { the City of Žilina and its urban area } \\
\text { [2017] }\end{array}$ & $\begin{array}{l}\text { - Short and medium-term solutions ( } 1 \text { to } 5 \text { years): Implementation of e-bike } \\
\text { sharing, Deployment of a low carbon zone within the 1st Urban Ring and } \\
\text { adjustment of parking policy (low carbon places), Introduction of e-buses in } \\
\text { urban transport, Installing Charging Stations Step 1, Installing charging stations } \\
\text { on the public lighting system } \\
\text { - Long term solutions (10-20 years): Expansion of (e)bike sharing, Introduction } \\
\text { of e-car sharing, Expansion of low carbon zones, Introduction of e-bus charging } \\
\text { stations at public transport stops (access to other areas), Introduction of WET } \\
\text { charging at parking spaces, Realization of accumulation points (energy HUB) }\end{array}$ & No linkage & [16] \\
\hline Bratislava & $\begin{array}{l}\text { Smart City Bratislava } 2030 \text { - Smart } \\
\text { City concept [2018] }\end{array}$ & $\begin{array}{c}- \text { Development of emission-free and low-emission transport, } \bullet \text { Introduction of } \\
\text { modern energy-saving and environmentally friendly technologies in the urban } \\
\text { infrastructure, } \bullet \text { Partnership of the city with commercial entities, research } \\
\text { organizations and public institutions }\end{array}$ & No linkage & [17] \\
\hline Žilina & $\begin{array}{c}\text { Concept of development of elec- } \\
\text { tromobility in Municipality of Žilina } \\
\text { [2018] }\end{array}$ & $\begin{aligned} \bullet \text { Charging infrastructure, } & \bullet \text { Low-emission zones, } \bullet \text { Information system of } \\
& \text { electromobility }\end{aligned}$ & Strategy [6] & [18] \\
\hline $\begin{array}{l}\text { Association of } \\
\text { municipalities }\end{array}$ & $\begin{array}{l}\text { Joint development program of the } \\
\text { Municipalities of region Oravské } \\
\text { podhradie [2015] }\end{array}$ & - Development of electromobility in Orava region & No linkage & [19] \\
\hline Poprad & $\begin{array}{c}\text { Development program of the } \\
\text { Municipality of Poprad for } 2016 \text { - } \\
2022 \text { with the outlook to } 2040 \\
\text { [2015] }\end{array}$ & $\begin{array}{l}\text { - Greening of transport through the development of non-motorized transport in } \\
\text { the city in combination with the use of ecological fuels in public transport } \\
\text { (electromobility), } \bullet \text { Note: the document assumes the adoption of the concept of } \\
\text { development of alternative transport modes and electromobility }\end{array}$ & No linkage & [20] \\
\hline Prešov & $\begin{array}{l}\text { Development program of the } \\
\text { Municipality of Prešov for } 2015 \text { - } \\
2020 \text { with the outlook to } 2025 \\
\text { [2016] }\end{array}$ & $\begin{array}{c}\bullet \text { Increasing the share of electromobility in public transport, • Equip- } \\
\text { ping/supplementing the municipal police fleet with alternative CNG, LPG, } \\
\text { electric vehicles/bicycles }\end{array}$ & No linkage & [21] \\
\hline Bardejov & Smart City Bardejov [2019] & $\begin{array}{l}\text { - The need for renewal of the public lighting system and its use for fiber optic } \\
\text { network and electromobility } \bullet \text { Identification of the need to develop an (local) } \\
\text { action plan for electromobility }\end{array}$ & $\begin{array}{l}\text { Action Plan } \\
\quad[9]\end{array}$ & [22] \\
\hline Nitra & $\begin{array}{l}\text { Smart City - Smart and modern } \\
\text { Municipality Nitra [2018] }\end{array}$ & $\begin{array}{c}- \text { Deploying of a network of charging stations } \bullet \text { Development of electromobility } \\
\text { - public transport } \bullet \text { Development of electromobility - individual transport } \bullet \text { Car } \\
\text { sharing - system of public electric vehicles }\end{array}$ & No linkage & $\begin{array}{l}{[23,} \\
24]\end{array}$ \\
\hline Senec & $\begin{array}{l}\text { Local Action Plan of e-mobility for } \\
\text { Municipality of Senec [2019] }\end{array}$ & $\begin{array}{l}\bullet \text { Municipality policy updates, } \bullet \text { Indirect support of electromobility, } \bullet \text { Educa- } \\
\text { tion, information and promotion of electromobility, } \bullet \text { The green procurement } \\
\text { principle of the municipality and its entities, } \bullet \text { Support of electromobility } \\
\text { infrastructure and services }\end{array}$ & Yes [6-10] & [25] \\
\hline Lučenec & $\begin{array}{l}\text { Audit of Municiplaty of Lučenec for } \\
\text { the involvement in the Smart City } \\
\text { program [2019] }\end{array}$ & $\begin{array}{l}- \text { Consider supporting the development of electromobility in connection with the } \\
\text { reduction of individual traffic in the centre, focusing on green public transport } \\
\text { Infrastructure of the public lighting system is suitable for making electromobility } \\
\text { accessible to residents (current infrastructure enables only slow charging) } \\
\text { Municipality will consider upgrading the infrastructure for electromobility or the } \\
\text { construction of parking houses }\end{array}$ & No linkage & [26] \\
\hline Pezinok & $\begin{array}{l}\text { Concept of ICT development in the } \\
\text { Municipality of Pezinok [2019] }\end{array}$ & $\begin{array}{l}\text { - Introduction of electromobility in the city (the basics of electromobility should } \\
\text { be created by combining bike sharing and creating a network of charging stations } \\
\text { for electric vehicles). }\end{array}$ & No linkage & [27] \\
\hline
\end{tabular}


The following parts are part of the analytical part:

- electromobility in the European context, trends in the EU, EU legislative and strategic framework,

- electromobility in Slovakia, policy framework and strategic documents of the Slovak republic,

- City of Senec, general characteristics of the city and its surroundings, statistical indicators,

- transport in the City of Senec, the fleet of Municipality of Senec, public transport,

- traffic in Senec and its surroundings, basic data on the road network, accessibility in Senec, road network load, road network load prospectively,

- externalities induced by transport, the contribution of electromobility to reducing emissions,

- development of electromobility, analysis of the economy of electric vehicles.

Within the proposal part, framework measures have been identified (see Table 1), each of which consists of sub-actions that specify the activities. The description of each measure was defined by the format negotiated within the eGUTS project consortium (Reference number, Action/Project name, Strategic document identification, Action/project description, Timeframe, Costs estimation/budget, Financing sources, Potential risks and barriers, Mitigation measures, Estimated impact, Project stages, Action/project holder/responsible department, Project custodian). For each of the measures, a detailed timetable for the project phase level (Gantt chart) and an explanation or comment is presented as well.

\section{Improving the readiness of munici- palities}

From the above mentioned follows that most municipalities are generally not sufficiently prepared for the development of electromobility due to personal and know-how reasons.

The following steps could improve the situation:

- centralising of information at national level on a single website,

- consultancy from the Ministry of Economy,

- taking part of municipalities in (international) projects or associations (clusters),

- cooperation with professional commercial subjects and citizens association (NGOs, action groups, voluntary organizations, ...) operating in the region in the field of electromobility,

- development of a comprehensive conceptual material (strategy, program, action plan, ...) for electromobility.

In this way, municipalities will achieve:

- access to information, best practices, trends,

- increasing of specialised competence and know-how,

- readiness for dynamically changing conditions,

- readiness for possible involvement in projects, grants and subsidy schemes (and thus to implement projects with a small share of own resources),
- possibility to build a functional ecosystem of electromobility.

\section{Conclusions}

The article analyses the national framework for electromobility in the Slovak Republic, which was established under the auspices of the Ministry of Economy of the Slovak Republic and where measures and objectives are defined, which have gradually begun to be implemented from the national level. The development of electromobility will depend not only on the consistency of state policy but also on how the municipalities will deal with this issue.

Experiences show that the approaches at the level of municipalities are very heterogeneous and, in case of lack of active attitude of municipalities, there may also occur excesses in the future (e.g. excess of demand for charging, insufficient infrastructure for charging station development, ...). Therefore it is necessary for cities to be prepared for the development of electromobility and to be able to respond adequately to the changing conditions. It can be expected that without a more proactive attitude of municipalities, the issue of electromobility will be conceptually solved insufficiently and the problems the municipalities will face will be dealt ad-hoc.

\section{ACKNOWLEDGEMENTS}

"This publication was realized with support of Operational Program Research and Innovation in frame of the project: ICT products for intelligent systems communication, code ITMS2014+ 313011T413, co-financed by the European Regional Development Fund"

\section{REFERENCES}

[1] Directive 2014/94/EU of the European Parliament and of the Council of 22 October 2014 on the deployment of alternative fuels infrastructure

[2] Directive 2009/28/EC of the European Parliament and of the Council of 23 April 2009 on the promotion of the use of energy from renewable sources

[3] M/468 Standardisation mandate addressed to CEN and CENELEC and ETSI concerning the charging of electric vehicles

[4] M/453 Standardisation mandate addressed to CEN, CE-NELEC and ETSI in the field of information and commu-nication technologies to support the interoperability of co-operative systems for intelligent transport in the Euro-pean community

[5] M/490 Smart Grid Mandate Standardization Mandate to European Standardisation Organisations (ESOs) to support European Smart Grid deployment

[6] Slovak government resolution No. 504/2015 on Strategy of electromobility development and its effect on Slovak economy (Original in Slovak). 
[7] Slovak government resolution No. 504/2016 on proposal of National political framework for development of alternative fuels market (Original in Slovak).

[8] Slovak government resolution No. 505/2016 on proposal of National policy of deployment of infrastructure for alternative fuels in conditions of the Slovak republic (Original in Slovak).

[9] Slovak government resolution No. 110/2019 on proposal of Action plan of electromobility development in the Slovak republic (Original in Slovak).

[10] Slovak government resolution No. 557/2019 on proposal of Revision and actualisation of National political framework for development of alternative fuels market (Original in Slovak).

[11] Čuboň, P., Hrudkay, K.: Systemic attitude to electromobility in Smart City concept, Proceedings of the conference Traffic Engineering 2017, Zilina (Original in Slovak), 2017.

[12] Košice development program for 2015-2020 (2025) [Online], Available: www.kosice.sk/mesto/program-rozvoja-mestakosice-na-obdobie-rokov-2015-2020 [2 Apr. 2020], 2015. (Original in Slovak),

[13] Development of electromobility in the environment of the Slovak capital Bratislava [Online], Available: https://zastupitelstvo.bratislava.sk/data/att/34316.pdf [2 Apr. 2020], 2013. (Original in Slovak).

[14] Action plan on adaptation to the adverse consequences of climate change in the capital of the Slovak Republic Bratislava for 2017-2020 [Online], Available: https://zastupitelstvo.bratislava.sk/data/att/14595.pdf [2 Apr. 2020], 2017. (Original in Slovak).

[15] Economic and social development program of the Municipality Michalovce for 2016-2025 [Online], Available: www.michalovce.sk/sk/clanok/strategicke-dokumenty [2 Apr. 2020], 2016. (Original in Slovak).

[16] Low carbon mobility action plan in the City of Žilina and its urban area [Online], Available: www.zilina.sk/strategicke-dokumenty-mesta/ [2 Apr. 2020], 2017. (Original in Slovak).

[17] Smart City Bratislava 2030 - Smart City concept [Online], Available: https://zastupitelstvo.bratislava.sk/data/att/38524.pdf [2 Apr. 2020], 2018. (Original in Slovak).

[18] Concept of development of electromobility in Municipality of Žilina [Online], Available: www.zilina.sk/strategicke-dokumenty-mesta/ [2 Apr. 2020], 2018. (Original in Slovak).
[19] Joint development program of the Municipalities of region Oravské podhradie [Online], Available: www.oravskypodzamok.sk/download file f.php?id=694564 [2 Apr. 2020], 2015. (Original in Slovak).

[20] Development program of the Municipality of Poprad for 2016 - 2022 with the outlook to 2040 [Online], Available: https://mobil.poprad.sk/download_file_f.php?id=685083 [2 Apr. 2020], 2015. (Original in Slovak).

[21] Development program of the Municipality of Prešov for 2015 - 2020 with the outlook to 2025 [Online], Available: www.presov.sk/prm-presov-2015-2020.html [2 Apr. 2020], 2016. (Original in Slovak).

[22] Smart City Bardejov [Online], Available: http://www.bardejov.sk/mestsky-urad/strategicke-a-rozvojov e-dokumenty-mesta/koncepcie-a-phsr [2 Apr. 2020], 2019. (Original in Slovak).

[23] Smart City - Smart and modern Municipality Nitra, Material for the City Council in Nitra of 15.12.2016 [2 Apr. 2020], 2016. (Original in Slovak).

[24] Concept Smart City of the Municipality of Nitra [Online], Available: http://www.smartcityvpraxi.cz/prezentace/Konference Smar cityvpraxiIII/Jozef_Dvonc_2018.pdf [2 Apr. 2020], 2018. (Original in Slovak).

[25] Local Action Plan of e-mobility for Municipality of Senec [Online], Available: www.senec.sk/sk/clanok/uzemny-plan [2 Apr. 2020], 2019. (Original in Slovak).

[26] Audit of Municiplaty of Lučenec for the involvement in the Smart City program [Online], Available: www.lucenec.sk/strategicke-dokumenty-mesta.phtml?id3=1 30460 [2 Apr. 2020], 2019. (Original in Slovak).

[27] Concept of ICT development in the Municipality of Pezinok [Online], Available: www.pezinok.sk/uploadfiles/File/msz/ 2019-11-28/MsZ_PK_2019-11-28-bod08.pdf [2 Apr. 2020], 2019. (Original in Slovak), 2019.

[28] Madleňák Radovan, Madleňáková Lucia, „Application of OSI reference model to the logistic systems", In: Archives of transport system telematics, pp. 35-39, 2016.

[29] Electric, Electronic and Green Urban Transport Systems, [Online], Available: www.interregdanube.eu/approved-projects/eguts $\left[\begin{array}{ll}2 & \text { Apr. }\end{array}\right.$ 2020], 2020. 